\title{
Similar outcome of ST-elevation myocardial infarction patients treated with primary percutaneous coronary intervention regardless of presence of cardiac surgery on-site
}

\author{
Jacek Legutko', Zbigniew Siudak¹, Stanisław Bartuś1 , Artur Dziewierz¹, Magnus Janzon², Ralf Birkemeyer ${ }^{3}$, \\ Krzysztof Żmudka ${ }^{4}$, Dariusz Dudek ${ }^{1}$ \\ ${ }^{1}$ Institute of Cardiology, Jagiellonian University, Medical College, Krakow, Poland \\ 2Division of Cardiovascular Medicine, Department of Medical and Health Sciences, Faculty of Health Sciences, Linköping University, \\ Department of Cardiology, County Council of Östergötland, Linköping, Sweden \\ ${ }^{3}$ Department of Cardiology, University of Rostock, Germany \\ ${ }^{4}$ Centre for Interventional Treatment of Heart Disease and Vessels, John Paul II Hospital, Krakow, Poland
}

\begin{abstract}
A bstract
Background: The growing penetration of mechanical reperfusion in ST-elevation myocardial infarction (STEMI) has been achieved by the creation of new percutaneous coronary intervention $(\mathrm{PCI})$ centres which have helped to shorten delays but have compromised $\mathrm{PCl}$ volumes.

Aim: To compare the outcomes in STEMI patients treated in PCl centres with or without surgical back-up.

Methods: Data concerning 1,650 registry patients was analysed. The analysis was based on cathlab classification with cardiac surgery on site $(n=996)$ and without $(n=654)$.

Results: There was a $0.3 \%$ rate of transfer (two patients out of 654 ) for urgent coronary artery bypass grafting from $\mathrm{PCl}$ centres without cardiac surgery on site. There were no differences in in-hospital and long-term mortality in patients in both studied groups. Conclusions: No differences in short and long-term outcomes were noticed for STEMI patients treated in centres with or without cardiac surgery on-site.
\end{abstract}

Key words: angioplasty, cardiac surgery, myocardial infarction

Kardiol Pol 2014; 72, 10: 949-953

\section{INTRODUCTION}

The introduction of primary percutaneous coronary intervention $(\mathrm{PCl})$ by the European Society of Cardiology (ESC) guidelines as the treatment of choice for ST-elevation myocardial infarction (STEMI) eligible patients (class IA) has led to the dynamic evolution of $\mathrm{PCl}$ centres in most European countries [1]. The growing penetration of mechanical reperfusion in STEMI, reaching over $80-90 \%$ in some regions in Europe, has been achieved by the creation of new $\mathrm{PCl}$ centres, including in rural areas far from large academic teaching hospitals. This has helped shorten delays, but at the same time it has compromised $\mathrm{PCl}$ volumes performed at such centres [2]. Doubts have been raised, supported by clinical data, that an uncontrolled spread of PCI capable hospitals may adversely impact not only the quality of care, but also survival [3-5]. Additional voices have also spoken against the separation of $\mathrm{PCl}$ in acute myocardial infarction from surgical on-site back-up [5, 6].

Our aim was to analyse the real life registry data from the EUROTRANSFER database in order to compare outcomes in STEMI patients treated in PCl centres with or without surgical back-up. 


\section{METHODS}

The current patient and invasive cardiology centre (cathlab) analysis was based on the EUROTRANSFER Registry data (ClinicalTrials.gov NCT00378391), the main results of which have already been published $[7,8]$. The registry database of 1,650 patients enrolled between 2005 and 2007 in 15 catheterisation laboratories in seven European countries (Poland, Sweden, Germany, Italy, Spain, Finland, and Slovenia) was researched. The study protocol complied with the Declaration of Helsinki and was approved by the Jagiellonian University Bioethics Committee in Krakow, Poland.

The primary analysis in this paper was based on the presence or absence of on-site (within one hospital area) cardiac surgery affiliated to the cathlab.

The primary end-points of this analysis were in-hospital, 30-day and one-year all-cause mortality. Additional end-points included all-cause death and non-fatal re-infarction and additional urgent revascularisation ( $\mathrm{PCl}$ or coronary artery bypass graft [CABG]) during the 30-day observation period. $\mathrm{PCl}$ general complications and bleeding events such as puncture site haematomas and major bleedings requiring blood transfusion (at least one pack of blood cells) were also assessed.

\section{Statistical methods}

Data was analysed according to the established statistical protocols. Results were presented as percentages of patients or means ( \pm standard deviation) where applicable. Differences between groups were tested using $\chi^{2}$ test and Mann-Whitney $U$ test for continuous variables. Kaplan-Meier survival curve was plotted for one-year survival and compared using log-rank test. All tests were two tailed and a $p$ value of less than 0.05 was considered to be statistically significant. Statistical analyses were performed using SPSS 20 (SPSS Inc., Chicago, IL, USA).

\section{RESULTS}

There were 996 (60\%) patients who were admitted to $\mathrm{PCI}$ centres with cardiac surgery on-site and 654 (40\%) patients admitted to cathlabs with no cardiac surgery on-site. Baseline characteristics and clinical status on admission, as well as procedural details of angiography and $\mathrm{PCl}$, were similar in both groups (Table 1 ). There was a $0.3 \%$ rate of transfer (two patients of 654) for urgent CABG from a $\mathrm{PCl}$ centre without cardiac surgery on site. There were no differences in in-hospital and long-term mortality in patients in both studied groups. Comparable one-year mortality in those patients who required immediate bypass surgery (CABG) was found in hospitals with and without cardiac surgery on-site (Table 2, Fig. 1). Of 15 participating centres, seven (47\%) were high primary $\mathrm{PCl}$ centres (> $300 \mathrm{PPCl}$ per year), and eight (53\%) were moderately low primary $\mathrm{PCl}$ centres $(<300 \mathrm{PPCl}$ per year). On-site cardiac surgery was available for four (57\%) high volume $\mathrm{PPCl}$ centres and for four (50\%) low volume $\mathrm{PPCl}$ centres $(p>0.05)$. The in-hospital and one year mortality of STEMI patients did not differ in low vs. high PPCl volume centres in our study $(7.6 \%$ vs. $8.9 \%, p=0.417)$.

\section{DISCUSSION}

The rapid expansion of $\mathrm{PCl}$ procedures for acute myocardial infarction in Europe over the past decade has led to an enormously high penetration of $\mathrm{PPCl}$ services in countries like Germany, Switzerland, Poland, Sweden and the Czech Republic [2]. The launching of more and more catheterisation labs, not only in academic centres and not always with on-site surgical back-up, has resulted in reasonable doubts as to whether the safety of patients in terms of clinical and periprocedural outcomes will remain secure in a low volume setting and in those without on-site surgery [3]. Historical data from Wennberg et al. [5] showed a significant mortality benefit if $\mathrm{PCl}$ was

Table 1. Demographics and angiography divided by on-site cardiac surgery

\begin{tabular}{|c|c|c|c|}
\hline & On-site $(n=996)$ & None $(n=654)$ & $\mathbf{P}$ \\
\hline Age & $63.7 \pm 12.5$ & $64.5 \pm 11.9$ & 0.184 \\
\hline Sex [males] & $73 \%(727)$ & $71 \%(464)$ & 0.481 \\
\hline Previous myocardial infarction & $11.5 \%(114)$ & $14 \%(92)$ & 0.079 \\
\hline Smoking habit & $36.5 \%(363)$ & $35.5 \%(232)$ & 0.735 \\
\hline Diabetes mellitus & $15 \%(149)$ & $18 \%(118)$ & 0.125 \\
\hline Previous PCl & $7 \%(70)$ & $8 \%(52)$ & 0.435 \\
\hline Killip $3+4$ on admission & $5.9 \%(59)$ & $4.6 \%(30)$ & 0.277 \\
\hline Radial access & $20 \%(199)$ & $3.5 \%(23)$ & 0.001 \\
\hline TIMI 3 in baseline angiography & $14 \%(139)$ & $13 \%(85)$ & 0.701 \\
\hline TIMI 3 post PCI & $96 \%$ (956) & $95 \%(621)$ & 0.319 \\
\hline
\end{tabular}

$\mathrm{PCl}$ - percutaneous coronary intervention; TIMI — Thrombolysis in Myocardial Infarction 
Table 2. Primary percutaneous coronary intervention ( $\mathrm{PCl}$ ) outcome and complications divided by on-site cardiac surgery

\begin{tabular}{|c|c|c|c|}
\hline & On-site $(n=996)$ & None $(n=654)$ & $\mathbf{P}$ \\
\hline \multicolumn{4}{|l|}{ Ischaemic complications } \\
\hline Death in-hospital & $3.8 \%(38)$ & $4.1 \%(27)$ & 0.796 \\
\hline Death at 30 days & $5.3 \%(53)$ & $5.4 \%(35)$ & 0.979 \\
\hline Death + reMl+ rev at 30 days & $8.4 \%(84)$ & $6.6 \%(43)$ & 0.186 \\
\hline Death at one year & $8.4 \%(84)$ & $8.3 \%(54)$ & 0.899 \\
\hline Urgent CABG in-hospital & $1.3 \%(13)$ & $0.3 \%(2)$ & 0.059 \\
\hline One-year death & $30.8 \%(4)$ & $50 \%(1)$ & 0.931 \\
\hline Urgent PCI in-hospital & $1.7 \%(17)$ & $0.9 \%(6)$ & 0.204 \\
\hline \multicolumn{4}{|l|}{ Bleeding in-hospital } \\
\hline Intracranial haemorrhage & $0 \%(0)$ & $0 \%(0)$ & - \\
\hline Puncture site haematoma & $7.5 \%(75)$ & $4.0 \%(26)$ & 0.003 \\
\hline Blood transfusion & $2.0 \%(20)$ & $1.1 \%(7)$ & 0.167 \\
\hline \multicolumn{4}{|l|}{ Time delays } \\
\hline Admission to balloon [min] & $36 \pm 24$ & $34 \pm 24$ & 0.690 \\
\hline \multicolumn{4}{|l|}{ PCl complications } \\
\hline No-reflow & $3.2 \%(32)$ & $2.8 \%(18)$ & 0.661 \\
\hline Distal embolisation & $1.6 \%(16)$ & $2.4 \%(16)$ & 0.274 \\
\hline Perforation & $0.2 \%(2)$ & $0 \%(0)$ & 0.521 \\
\hline Tamponade & $0.2 \%(2)$ & $0 \%(0)$ & 0.373 \\
\hline Side branch occlusion & $1 \%(10)$ & $0 \%(0)$ & 0.008 \\
\hline
\end{tabular}

reMI - repeat myocardial infarction; rev — revascularisation; CABG — coronary artery bypass grafting

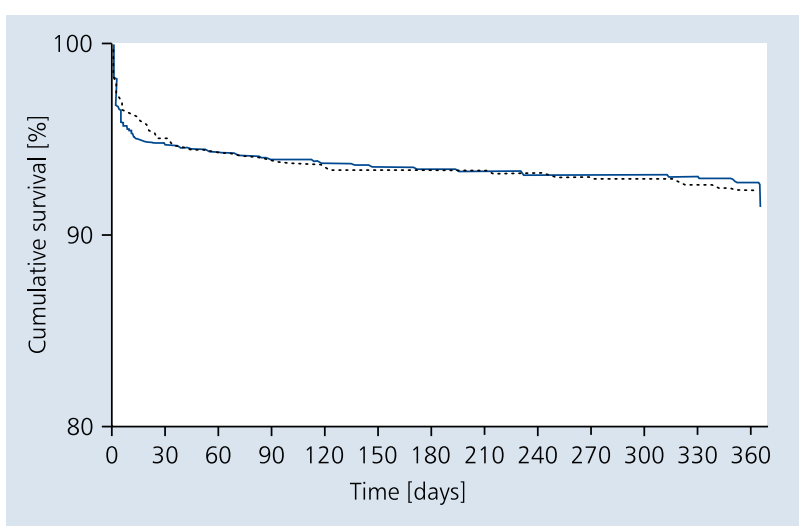

Figure 1. Kaplan-Meier survival curves for patients treated in invasive cardiology centres without cardiac surgery on-site (fine line) and with cardiac surgery on-site (dotted line). Statistically non-significant $p=0.799$ (log-rank test)

performed in hospital with surgical back up. In 2001, the American College of Cardiology/American Heart Association issued a class III recommendation for performing angioplasty in centres with no surgery on-site [6]. Real life has verified these recommendations and alarmist voices have turned out to be at least exaggerated in terms of the high demand for life and quality of life saving procedures like PCls. Current ESC guidelines recommend that minimal minimum of 0.3 million inhabitants should comprise one $\mathrm{PCl}$ centre [1].

Some more recent papers have indicated that it is a well-organised high volume system that influences the outcome most, not factors concerning the operators, and the experience of the whole team plays a major role $[9,10]$. A study by Wharton et al. [11] goes further, concluding that the transfer of high risk acute myocardial infarction patients to hospitals with surgical back-up postpones reperfusion by more than $60 \mathrm{~min}$, provides similar safety, and a 30-day death rate of $8.5 \%$ compared to $3.4 \%(p=0.054)$ in patients treated in $\mathrm{PCl}$ centres without surgery on-site.

The most striking finding in the EUROTRANSFER Registry data, however, is the scarce need for urgent CABG in patients treated in hospitals with no on-site cardiac surgery (ca. $0.3 \%$ ). This translates to one patient a year who needs to be dispatched for surgery in a centre with $300 \mathrm{PPCI}$ per year. Does this justify the need for on-site surgery if the outcome is the same? It also seems that the presence of surgeons on-site makes invasive cardiologists more inclined to send their patients to their colleagues $(0.3 \%$ vs. $1.3 \%, p=0.059)$, while the outcome of patients treated by cardiac surgeons is fairly low in both situations (mainly due to poorer baseline clinical 
characteristic of patients). High volume $\mathrm{PPCl}$ centres with cardiac surgery on-site are becoming a rarer commodity as more cathlabs are launched every year. We believe that our results support the role and safety of $\mathrm{PCl}$ centres who work on a daily basis without surgical back up on-site. In our study, we observed more frequent access site bleeding complications in a group of patients treated in cathlabs with on-site surgery. These have not, however, triggered major bleeding complications requiring transfusions which were equally distributed between the groups. The outcome may result from factors the influence of which was not recorded in this study.

The EUROTRANSFER registry was performed in 15 invasive cardiology centres in Europe and may thus reflect only the situation in these centres and regions of Europe.

\section{CONCLUSIONS}

No differences in short and long-term outcome were noticed for STEMI patients treated in centres with or without cardiac surgery on-site.

\section{Conflict of interest: none declared}

\section{References}

1. Steg PG, James SK, Atar D et al. ESC Guidelines for the management of acute myocardial infarction in patients presenting with ST-segment elevation. Eur Heart J, 2012; 33: 2569-2619.

2. Widimsky P, Wijns W, Fajadet J et al. Reperfusion therapy for ST elevation acute myocardial infarction in Europe: description of the current situation in 30 countries. Eur Heart J, 2010; 31: 943-957.

3. O'Neill W. A case against low-volume percutaneous coronary intervention centers. Circulation, 2009; 120: 546-548.
4. McGrath PD, Wennberg DE, Dickens JD Jr et al. Relation between operator and hospital volume and outcomes following percutaneous coronary interventions in the era of the coronary stent. JAMA, 2000; 284: 3139-3144.

5. Wennberg DE, Lucas FL, Siewers AE et al. Outcomes of percutaneous coronary interventions performed at centers without and with onsite coronary artery bypass graft surgery. JAMA, 2004; 292: 1961-1968.

6. Smith SC Jr, Dove JT, Jacobs AK, et al. ACC/AHA guidelines of percutaneous coronary interventions (revision of the 1993 PTCA guidelines): executive summary. A report of the American College of Cardiology/American Heart Association Task Force on Practice Guidelines (committee to revise the 1993 guidelines for percutaneous transluminal coronary angioplasty). J Am Coll Cardiol, 2001; 37: 2215-2239.

7. Dudek D, Siudak Z, Janzon M et al. European registry on patients with ST-elevation myocardial infarction transferred for mechanical reperfusion with a special focus on early administration of abciximab: EUROTRANSFER Registry. Am Heart J, 2008; 156: 1147-1154.

8. Siudak Z, Rakowski T, Dziewierz A et al. Early abciximab use in ST-elevation myocardial infarction treated with primary percutaneous coronary intervention improves long-term outcome. Data from EUROTRANSFER Registry. Kardiol Pol, 2010; 68: 539-543.

9. Harjai KJ, Berman AD, Grines CL et al. Impact of interventionalist volume, experience, and board certification on coronary angioplasty outcomes in the era of stenting. Am J Cardiol, 2004; 94: 421-426.

10. Politi A, Galli M, Zerboni S et al. Operator volume and outcomes of primary angioplasty for acute myocardial infarction in a single high-volume centre. J Cardiovasc Med (Hagerstown), 2006; 7: 761-767.

11. Wharton TP Jr, Grines LL, Turco MA et al. Primary angioplasty in acute myocardial infarction at hospitals with no surgery on-site (The PAMI-No SOS Study) versus transfer to surgical centers for primary angioplasty. J Am Coll Cardiol, 2004; 43: 1943-1950. 


\title{
Podobne rokowanie pacjentów z zawałem serca $z$ uniesieniem odcinka ST poddawanych pierwotnej angioplastyce wieńcowej niezależnie od obecności oddziału kardiochirurgii na miejscu
}

\author{
Jacek Legutko', Zbigniew Siudak ${ }^{1}$, Stanisław Bartuś ${ }^{1}$, Artur Dziewierz ${ }^{1}$, Magnus Janzon², Ralf Birkemeyer ${ }^{3}$, \\ Krzysztof Żmudka ${ }^{4}$, Dariusz Dudek ${ }^{1}$ \\ 'Instytut Kardiologii, Uniwersytet Jagielloński Collegium Medicum, Kraków \\ 2Division of Cardiovascular Medicine, Department of Medical and Health Sciences, Faculty of Health Sciences, Linköping University, \\ Department of Cardiology, County Council of Östergötland, Linköping, Szwecja \\ ${ }^{3}$ Department of Cardiology, University of Rostock, Niemcy \\ ${ }^{4}$ Klinika Kardiologii Interwencyjnej, Instytut Kardiologii, Uniwersytet Jagielloński Collegium Medicum, \\ Szpital im. Jana Pawła II w Krakowie, Kraków
}

\section{Streszczen i e}

Wstęp: Coraz większy odsetek chorych z zawałem serca z uniesieniem odcinka ST (STEMI) leczonych metodami przezskórnej angioplastyki wieńcowej (PCI) został osiągnięty poprzez tworzenie nowych pracowni kardiologii inwazyjnej, co pozwoliło skrócić czas do uzyskania docelowej terapii.

Cel: Celem pracy było porównanie rokowania pacjentów z STEMI leczonych PCI w ośrodkach z bezpośrednim zabezpieczeniem kardiochirurgicznym i bez niego.

Metody: Zebrano dane dotyczące 1650 pacjentów. Spośród nich 996 było leczonych w pracowniach kardiologii inwazyjnej z zabezpieczeniem kardiochirurgicznym na miejscu, a 654 bez bezpośredniego zabezpieczenia kardiochirurgicznego.

Wyniki: W grupie pacjentów z pracowni bez oddziału kardiochirurgii na miejscu tylko 0,3\% osób z STEMI (2 chorych z 654) zostało przekazanych do pilnej operacji pomostowania aortalno-wieńcowego. Nie zaobserwowano różnic w śmiertelności odległej w obu porównywanych grupach w 12. miesiącu po PCI.

Wnioski: Obecność oddziału kardiochirurgii na miejscu nie jest wymogiem koniecznym do prowadzenia interwencyjnego leczenia zawału serca w pracowniach kardiologii inwazyjnej i nie wiąże się z lepszymi odległymi wynikami klinicznymi.

Słowa kluczowe: angioplastyka, kardiochirurgia, zawał serca

Kardiol Pol 2014; 72, 10: 949-953 